\title{
Complex microbial interactions affect colonization of cooling towers by Legionella
}

Kiran Paranjape

Émilie Bédard

Deeksha Shetty

MengQi Hu

Fiona Chan Pak Choon

Michèle Prévost

Sébastien P. Faucher

\section{Video Byte}

Keywords: Microbiome, 18S rRNA gene amplicon sequencing, eukaryotic community, Legionella, pneumophila, Brevundimonas sp., dissolved organic carbon, network analysis, Whole Genome Sequencing, eukaryotes, cooling tower, microbial ecology, Legionnaires' Disease

Posted Date: February 25th, 2021

DOl: https://doi.org/10.21203/rs.3.rs-275902/v1

License: (c) (i) This work is licensed under a Creative Commons Attribution 4.0 International License.

Read Full License 


\section{Abstract}

Cooling towers are home to unique ecosystems of microorganisms. While many are harmless, some are pathogenic. Cooling towers have been linked to many outbreaks of Legionnaires' disease, a severe pneumonia caused by Legionella bacteria. A new study sought to identify microorganisms associated with cooling tower colonization by Legionella. Researchers identified complex ecological networks highlighting the importance of other bacteria and primary producers. For example, the presence of Brevundimonas bacteria was associated with higher levels of Legionella. Brevundimonas is prey for a Legionella host species, Tetrahymena. But Brevundimonas also directly stimulated the growth of Legionella in laboratory experiments. This study suggests that the Legionella host community is not the only factor that leads to Legionella outbreaks. Entire groups of microorganisms and their interactions play complex roles. Future work is needed to better understand these networks and how they vary over time. Those insights could be used to manipulate cooling tower microbiomes to reduce the presence of Legionella. 